\title{
Amalie Nielsens erindringer fra 1864 og følgende år
}

\author{
Af $\dagger$ Jens Holdt.
}

I "Sønderjyske Årbøger “ 1956 har pastor H. F. Petersen udgivet præstedatteren Amalie Nielsens barndoms- og ungdomserindringer - med en fyldig indledning om denne betydelige sønderjyske kvindes livsdata. Hendes afsluttende afsnit med titlen »De år jeg var bondekone* blev efter familiens ønske på grund af dets delvis private karakter udeladt. Det er dog kort refereret i redaktør N. Petersens skildring af hende i H. Tonnesens torso-skrift "Nordslesvigsk Kirkeliv«, 1. hæfte 1926. Da imidlertid, forekommer det mig, også dette sidste afsnit bringer historisk værdifulde optegnelser fra skxbneåret $1864 \mathrm{og}$ den begyndende danske samling efter nederlaget og den nye tyske sejr i 1870, med de første små spirer især på kirkelivets område, offentliggøres det her med familiens tilladelse $i$ et skønsomt udvalg. Vi hører om den danske kirkelige mødevirksomhed i private hjem, større kirkelige mader nord for den nye statsgrænse, Elise Lindbergs virke for ansættelse af danske lærerinder i nordslesvigske hjem, mejerivæsenets forbedring, fru Nielsens egen sociale indsats og hendes betydningsfulde arbejde sammen med hendes mand, gårdejer Jes Nielsen, Kassø, Hjordkær sogn, for udgivelsen af en ny dansk slesvisk salmebog.

\section{Da jeg var bondekone.}

Da Peter ${ }^{1}$ var $1 / 2$ år gammel, var vi til et kirkehistorisk møde $\mathrm{i}$ Ribe, der varede $\mathrm{i}$ to dage. Vi havde Peter med, og Elsæbe som barnepige. Vi kørte hjemmefra og lige til Hjortlund, det var en lang og trættende tur. Klokken blev over 10 om aftenen, før vi nåede Hjortlund, hvor vi blev venligt modtaget af onkel Julius og tante Trine, som jeg havde skrevet til, at vi kom.

Den følgende dag kørte vi så alle ind til Ribe. Der blev holdt mange gode foredrag, og vi mødtes her med mange rare og interes- 
sante mennesker. Den følgende nat logerede jeg og Peter hos Anna Balslev, ${ }^{2}$ der var blevet gift med adjunkt Koch og boede $\mathrm{i}$ Ribe. Nielsen havde Anna fået anbragt i et hus ikke langt derfra, for de havde ikke plads nok til også at have ham, da Kochs forældre, provst Koch i Døstrup, også boede ved dem. Den dag tror jeg nok, at mødet blev afsluttet så tidligt, at vi nåede at komme hjem samme dag.

Så gik et år fredeligt og godt, den vinter abonnerede Nielsen på en læseforening i Åbenrå, hvorfra vi fik forskellige gode bøger. Men så kom krigen!

I efteråret, da vi fik at vide, at Frederik den Syvende var død, stod det straks klart for os begge, at vi snart ville få krig.

Nielsen blev valgt til, sammen med fem andre, at overbringe Kristian IX Sønderjyllands lykønskning til hans tronbestigelse.

De fem andre var: Lxrer Jørgensen ug Nissen, Viby, fra Als, Petersen, Hostrup, Jakobsen, Terp, og en angelbo, hvis navn jeg ikke husker, men jeg har portrætterne i mit album. Jeg husker ikke nøjagtig, hvad tid de rejste, dog antager jeg, at det har været straks, allerede før jul [7/12].

Hans Møller blev indkaldt til krigstjeneste sammen med tre andre unge karle fra Kassø, hvis navne jeg ikke husker.

De drog afsted med et frejdigt mod, forsynet med en god madpose. $\mathrm{Da}$ vinteren var meget hård, hørte vi dog snart, at soldaterne trængte til at få noget varmt uldtøj, og alle gav sig nu til at strikke forskellige ting, som man tænkte, de kunne have brug for, og så blev Andreas Kristian (kaldet Fyt) sendt derop. Han kom hjem igen med den forsikring, at de var uforknytte (ved Dannevirke), men den stolteste karl $\mathrm{i}$ hele hæren, det var hans egen søn, Peter Toft. Det lo folk jo af.

Så kom der ordre til en masse ægtvogne, der skulle møde ved Dannevirke. Da sagde Nielsen: »Du skal se, at de trækker sig tilbage fra Dannevirke, de kan slet ikke holde denne stilling.«

Markus tjente hos os den gang, og han blev nu sendt i ægtkørsel med vore stærkeste heste, og Nielsen sagde til ham: $\gg D u$ må se til, at du kommer til at gøre nytte med befordringen «, for der var desværre mange, der kneb ud og kørte hjem uden at gøre nytte, når de kunne se lejligheden dertil.

Markus nåede nok ikke længere end til Flensborg, men der kom 
han så til at køre med nogle officerer til Sønderborg, og undervejs tog de op så mange, de kunne, af dem, der trængte hårdest. Det så jo frygteligt ud på chausseen, da føret var så forfærdelig glat, så både kanoner og vogne væltede hist og her. Markus kom dog godt over broen, og tilbage over broen igen, før vejen blev spærret. Der var mange, der måtte blive derovre, blandt andet Laust, Mattes Andresens søn i Sønder Ønlev med hans anden kone. Da Markus kom hjem, ville jeg give ham noget at spise, men han kunne ikke spise, blot sove, han sov et helt døgn, før han kom sig så meget, at han kunne nyde noget.

Det var den 5. februar, at de retirerede fra Dannevirke. Mange kom ad Oksevejen og gik nordpå, som de bedst kunne.

Gxstgiveren i Petersborg var tysksindet, men han var dog så menneskelig, at han slagtede en stud, kogte suppe og bespiste alle dem, der kom til kroen. I Toldsted var der fuldt af soldater hele natten, og alle byens koner gik derhen for at hjælpe med at skære smørrebrød, og da fødemidlerne slap op, blev der sendt vogne til de nærmeste byer for at hente mere. Til Kassø kom der også en vogn. Vi havde lige bagt, og vi gav dem nu alle brødene med undtagelse af et par, vi selv måtte have, indtil vi kunne få bagt igen, så en balje smør og noget pålæg, hvad vi lige havde, og sådan gjorde de også fra de andre gårde.

I Hjordkær, hvor husmændene var meget dansksindede, sagde de til soldaterne: "Læg I jer kun trygt til at sove i vore senge, vi skal nok holde vagt «. Så tog de et lagen om sig for at være hvide som sneen og gik ud at passe på. Der kom dog ingen fjender endnu. I Toldsted gjorde kagekonen en god forretning, hendes kurve var tømt på et øjeblik, men så gik hun tilbage for at hente mere. Men de stakkels soldater var $\mathrm{i}$ en ulykkelig forfatning, de trak deres strømper af, vred vandet af dem og trak dem på igen. I Nørre Ønlev stegte de flæxsk hele natten og bespiste så mange, de kunne ...

Krigsbyrden kom nu særlig til at hvile på Dybbøl og de der $\mathrm{i}$ nærheden liggende byer. De byer, der lå længere borte fra krigsskuepladsen, sendte derfor bud til dem, at de gerne ville yde dem lidt hjælp med, hvad de kunne. Der kom da en indsidderfamilie til at bo i Peter Grevsens aftægtshus, og vi fik en sort hest $i$ foder...

Der blev også kørt en del fourage til de betrængte byer i Dybbølstillingen, for militærhestene havde ædt alt deres halm, så de intet 
havde til deres egne kreaturer. Vi kunne tydeligt høre, når de skød på skanserne ved Dybbøl, og jeg lå tit ude på græsplænen og hørte, hvorledes den ene salve kom efter den anden...

En gang midt om sommeren kom Peter Søgaard hjem. Han var blevet taget til fange af prøjserne, men da de hørte, han var sønderjyde, gav de ham fri. Vi spurgte, om de ikke gjorde nogen betingelse, før de gav ham fri. Dertil svarede han nej, men der har nok været en hage derved, for Anna Stadils broder blev også taget til fange, men han blev sendt til en østrigsk fæstning. Han skrev til hende, og jeg måtte $\mathrm{i}$ hendes navn besvare hans brev...

Vi fik snart velsignelsen ved det prøjsiske regimente at føle, men forstod ikke altid at sætte pris på den. Vi måtte ikke bage i vore bageovne, fordi der ingen lejevåning var i samme hus. De, der havde en lejevåning ved siden af, måtte. Man skulle tro, det modsatte havde været mere rimeligt, men det var nu den prøjsiske lov. Vi gjorde så akkord med en bager, der leverede os brød for rug, og så byggede vi et nyt bagehus $i$ den afstand, loven foreskrev...

Så kom den ærgerlige kommuneforstanderhistorie. Nielsen var valgt til kommuneforstander og havde været det $\mathrm{i}$ længere tid, men nu blev der forlangt af ham, at han skulle aflægge ed til kongen af Prøjsen, og det ville han ikke. Imidlertid havde bønderne i Kassø truffet en overenskomst imellem dem selv, at dette embede skulle gå på omgang fra den ene til den anden, og det var vist meningen, at hver enkelt skulle være kommuneforstander i 3 år. Far mente nu, at når han ikke ville aflægge eden, havde den nærmeste efter ham, der ville aflægge eden, at tage fat, men det mente bonderne ikke.

Jeg synes nu, det var lumpent af bønderne, at de ikke ville vedstå den akkord, de tidligere frivilligt havde indgået, men det var dumt af Nielsen at føre proces $i$ den sag, for han kunne jo let tænke sig, at han ville tabe den, da hans forbrydelse jo bestod deri, at han ikke ville aflægge ed til kongen af Prøjsen. Det kom så til proces, og Nielsen blev dømt til at leje en kommuneforstander i sit sted, der ville aflægge eden. Han lejede da Hans Jørgensen af Vilby, som han måtte betale af sine egne penge for den tid, han var det, indtil de år var gået, da Nielsen skulle være det.

Hans Jørgensen var forresten meget skikkelig ved dette arbejde, de gjorde arbejdet i fxllesskab, og det blev alt således, som far ville have det. Akterne fra denne proces må ligge i den grønne kiste. 
1865 gjorde vi en rejse til Nørre Broby for at besøge Balslevs, vi havde begge børnene med, og Inger som barnepige. Denne gang måtte vi rejse til Flensborg, derfra med dampskib til Svendborg, hvor vi lejede en vogn til at køre os til Norre Broby.

Det var en dejlig tur, det kimede til pinsefest, da vi kørte ind $\mathrm{i}$ Norre Broby præstegård. Det var meget smukt dér, der var en stor,

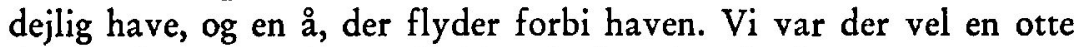
dages tid. Far gjorde en afstikker derfra til København, og jeg gjorde sammen med min søster en dejlig tur til Horne ved Fåborg, hvor fru Mogensens far, Rasmus Balslev fra Hårslev, var kapellan hos sin svigerfader, pastor Leth. Pastor Leth havde mange døtre, den xldste er tante Trine, som er gift med onkel Julius. Fru Mogensens mor var den yngste. Georgia er gift med pastor Teilmann.

Det var en dejlig dag. Der var to ugifte døtre hjemme, der sang mange smukke sange for os. Dér hørte jeg for første gang: "I sne står urt og busk $\mathrm{i}$ skjul« og Fædreneland! Ved den bølgende strand....

Vi rejste hjem samme vej og besøgte med det samme Monrads i Flensborg. Monrad havde $\mathrm{i}$ den danske tid været lærer ved latinskolen i Flensborg. Da tyskerne sejrede, tog han sin afsked og oprettede en stor privatskole i Flensborg. I den var der både tysk og dansk undervisning, og den gjorde megen gavn. Monrad blev snart den øverste leder af den danske forening, som var organiseret over hele Nordslesvig. Junggreen ledede den i Ảbenrå, og Nielsen i Hjordkær og tilgrænsende sogne på landet. Nielsen stod derfor $\mathrm{i}$ stadig forbindelse med Monrad, og vi har også flere gange besøgt dem i Flensborg...

Imidlertid var Michaelsen blevet prast $\mathrm{i}$ Bjolderup, og han ordnede nu, i samarbejde med andre præster, en række missionsmøder. De andre præster var Clausen, Dybbøl, Lawaetz, der dengang var i Skrydstrup, og en, der hed Neergaard, der prædikede bedst af dem alle. Jeg mindes en aldeles glimrende tale over Ezekiel 37, 1-14 om de døde ben, der skulle vækkes til live ved Herrens ånd. $\mathrm{Da}$ den lille Niels Christian nu var død, og jeg trygt kunne stole på, at Ann Kathrin nok skulle passe Peter og Jep, var jeg med til flere af disse missionsmøder $\mathrm{i}$ Bjolderup, $\mathrm{i}$ Rise, og til et meget bevæget missionsmøde i Øster Løgum. ${ }^{3}$

Vi kørte sammen med Nis Callesens og spændte fra i Lerskov. 
Marie ville ikke have været med i kirke, men jeg fik hende til at gå med. Så var vi hos Kiers i Øster Løgum, ${ }^{4}$ hvor vi spiste middag, og der kom også pastor Michaelsen for at tale med hende. Jeg mindes ikke, om vi var med til flere missionsmøder den gang, men så var vi blevet bekendt med Petersens i Lunderup, som indbød os til deres rejsegilde. Vi gav dem hver en lanestol og var så der til rejsegilde, hvor der blev holdt flere taler. Der dannedes nu en mindre kreds, der holdt små kristelige møder i hjemmene. Der var foruden os Petersens i Lunderup, Biehls i Hønkys og Gotfredsens i Mjøls. Ved disse møder taltes der mest af lægmænd. Petersen ville gerne tale, men kunne kun fortælle om sin omvendelse, og det kunne jo ikke blive ved at byde stof. Så var der et par kolportorer fra Danmark, Jæungyde talte godt og sang nogle sange. Pastor Grønning ${ }^{5}$ i Åbenrå, der havde været præst $\mathrm{i}$ Østindien og tilhørte herrnhutermenigheden, talte engang hos Biehls. Senere talte også Mads Jensen," der holdt virkelig gode kristelige foredrag, og Hans, der tjente hos Gotfredsens, han har skrevet meget $\mathrm{i}$ "Ugens Nyheder « under mærket Hagbard, er vist også endnu lærer på en højskole. Når der skulle være møde hos os, sendte vi altid bud rundt $\mathrm{i}$ byen, og vi fik altid huset fyldt. Vi skulle melde det til sognepræsten, det gjorde vi også, men han kom aldrig. Der kom tit fremmede til os. Var det folk, der tilhørte den danske forening, så blev der sunget danske fædrelandssange, var der nogle, der var med i den kirkelige forening, blev der sunget salmer, til begge dele accompagnerede vi $\mathrm{i}$ reglen på pianoet.

Vi kørte også en gang imellem til møderne $\mathrm{i}$ Bovlund. Vi spændte da altid af hos Bunde Refslund, hvor vi blev modtaget med megen venlighed. På møderne hørte vi ikke alene mange gode taler, men blev også bekendt med en hel del rare folk.

Der var et stort møde i Vojens, jeg ved ikke, om det var 1867 eller 1868.7 Der blev stiftet en Kristelig Forening for Nordslesvig, jeg var med til dette møde. Vi havde kun én præst med som dirigent og ordstyrer, det var pastor Prahl, der var præst i Øster Logum i 1848. Han var tysksindet og kom derfor til Wetzlar, der dengang var prøjsisk enklave imellem Hannover og Hessen. Efter 1864 kom han tilbage og blev provst $\mathrm{i}$ Haderslev. Han var en fornuftig og praktisk mand, og ikke fanatisk og tysk.

En af lederne i denne forening var lærer Hansen i Gl. Haderslev, hvis kone var en søster til advokat Becker $\mathrm{i} A$ Ảbenrå, der altid overtog forsvaret for danske sager, der førtes proces om. 
Så var der en kandidat Jakobsen ${ }^{8}$ fra Haderslev, en søn af orgelbygger Jakobsen, Haderslev, der var tysksindet, men begge hans sønner fra den første kone var danske, både denne teologiske kandidat og orgelbyggeren, der overtog faderens forretning.

Kandidat Jakobsen havde også sin kone med til dette møde, det var en yndig ung pige. Mads Jensen fra Jegerup var også med og en del flere.

Så var Nielsen også med til et 2 dages møde i Haderslev. Det var et landbomøde, og Nielsen var den første dag med til en udflugt på landet og har vist den nat logeret hos en bonde, medens jeg, der den første dag besøgte larer Hansen, Gl. Haderslev, om natten logerede hos orgelbygger Jakobsen, og den anden dag var både min mand og jeg hos pastor Johansen, han havde en yndig kone, og der traf vi sammen med pastor Bruhns ${ }^{9}$ fra Gram, han var gift med en datter af biskop Hansen på Als.

Vi var også en gang til et stort 2 dages møde i Kolding, hvor vi hørte missionær Børresen. Dér talte også både pastor Andreas Leth ${ }^{10}$ og pastor Birkedal, det var et udmærket møde, dog husker jeg ikke, hvad år det var, det kan godt være, det var samme år senere. (Jeg så nylig i et blad, at det var først 1876).

Hen imod efteråret havde Nis Callesen og vi i fællesskab et stort missionsmøde. Vi havde de langvejs fra kommende talere til middag, og Nis Callesen havde det egentlige missionsmøde og de fremmede, der blev til fællesspisning bagefter.

Talerne var pastor Johansen fra Haderslev og pastor Michaelsen fra Bjolderup. Bruhns fra Hostrup var også hos os til middag...

En af præsterne havde valgt den salme: "Kæmp alvorlig om Guds nåde «, men så var der ingen, der kunne begynde på melodien, så begyndte den unge Bruhn, han sang meget godt, og det gik udmærket.

$\mathrm{Da}$ de nu var færdige med at få arvesagen i orden, ${ }^{11}$ ville præsten sige farvel, men jeg bad ham om dog først at tale til den gamle, ord til opbyggelse og trøst. Dette gjorde han nu, han kunne nok, men han gjorde det ikke uopfordret.

I de nætter, jeg vågede hos morbror, begyndte jeg at skrive på min første danske fortælling $»$ Fiskerhytten og præstegården «...

Jeg havde begyndt at læse med mine børn. Med Peter gik det meget let, han lærte hurtigt at læse, og da han blev noget større, lærte han også snart at skrive nogenlunde korrekt. Jep derimod havde 
svært ved at få lært at læse flydende, det kan dog gerne være, at jeg selv havde nogen skyld deri, jeg tror, jeg har begyndt for tidligt med ham. Alle børn er jo ikke lige tidlig udviklede, desuden var de $\mathrm{ABC}$-bøger, man havde dengang, ikke nær så gode som de nye $\mathrm{ABC}$ bøger, som er indrettet efter lydmetoden, med dem er det meget let at lære børn at læse. Til min aftenskole i Hjordkær havde jeg allerede købt en bog med meget smukke bibelske billeder.

Denne bog havde jeg megen nytte af, når jeg fortalte bibelhistorie. Billederne gjorde fortællingerne mere levende. $\mathrm{Nu}$ havde jeg fået én mere i min lille skole, men Lena kunne allerede læse, og det var jeg glad ved.

Lena ${ }^{12}$ sagde til mig sidste gang, jeg var i Grimstrup, at det vist havde været rigtigere, om jeg havde ladet Eder gå i skole hos Nissen [landsbylæreren], men dette er en fuldstændig falsk mening. Det ville have været uforsvarligt, om jeg havde ladet Eder spilde den kostbare tid og ungdomskraft ved at lære en masse ord udenad, uden at få nogensomhelst klarhed til forståelse af det, I lærte, uden at favne åndslivets inderste kerne, som alene kan udvikle sjælens vækst.

Snarere tror jeg, det var urigtigt af mig at lade Lena gå op til frk. Frandsen [dansk privatlærerinde], hun følte sig dér overset og tilsidesat, det kan godt være, jeg alligevel bedre selv ville kunne fængsle hendes opmærksomhed til fuld udvikling af hendes naturlige evner.

Da Peter blev 11 år, kom han jo til at gå til Bolderslev, og Clausen $^{18}$ var jo en udmærket lærer, men det var jo kedeligt, at det var alt for langt. Jep og Niels kom jo desværre ikke til at gå der så lenge...

Der kom hos os mange koner og småpiger, som tiggede, særlig fra de magre hedebyer Mjøls og Hostrup. På disse byers mark boede mange familier, der ejede en lille jordlod, som de ikke forstod at afvinde noget udbytte, og de gik da omkring og tiggede.

Jeg havde tit tænkt på, om der ikke kunne gøres noget for dem. $\mathrm{Nu}$ efter morbrors død havde jeg frie hænder, og jeg fik da en forening dannet med det dobbelte formål at få småpigerne lart at sy og at få konerne til at blive hjemme, passe deres husvæsen nogenlunde og sørge for deres børns pleje, så mente jeg, de burde udfylde deres overflødige tid med at spinde eller gøre noget andet hånd- 
arbejde, hvorved de kunne tjene lidt. Man havde sagt mig, at disse koner, når man gav dem gamle klæder, der ikke kunne bruges, akkurat som de var, ikke syede dem om og lempede dem til deres brug, men smed dem hen $i$ en krog og lod dem ligge at rådne.

Det kunne dog undskyldes noget med, at de, før de blev gift, kun havde tjent som malke- og markpiger og derfor heller ikke forstod at omsy sådant gammelt tøj, som blev givet dem. Den forening, jeg fik dannet, strakte sig over Kassø, Øbening, Hønkys og Hostrup. Der må endnu blandt mine papirer findes et program over foreningens opgaver og fortegnelse over dens medlemmer. Nogle gjorde indvendinger, fordi jeg ikke agtede på sognegrænsen, men jeg sagde, det gjaldt om at hjælpe dem, der trængte hårdest, og det lykkedes mig at overvinde deres betænkeligheder. Vi fik nu nogle penge samlet og noget hør købt. De koner, som ville spinde, fik betaling for deres arbejde og adgang til for halv pris at få noget af det lærred, vi fik forarbejdet. En fik et lagen, en anden en skjorte eller en særk, som vi nu syntes, de trængte til eller havde fortjent med deres arbejde.

Denne del af foreningens arbejde ledede Mathias Jensens kone i $\varnothing$ bening efter aftale med mig. Hun var en venlig, godmodig kone, der forstod sig godt på vævning, og hvad derhen hørte, men hun var vist noget indskrænket og vel heller ikke rigtig klar over, hvad hensigten var med dette. Det var måske heller ikke rigtig praktisk indrettet.

Med den sag arbejdede vi kun et par år, så gik den overstyr. Havde det været nu, havde vi vel givet konerne anvisning på roearbejde, men det kendte man ikke dengang. Hensigten var dog ikke blot at afholde konerne fra at tigge, men også at få dem til at tage sig af deres egne hjem. Jeg fik dog senere i Jelling sat noget lignende $i$ gang.

Det andet formål med vor forening, at lære småpigerne at sy, var derimod praktisk og højst fornødent, thi dengang havde man endnu ingen lovbefalede syskoler, og de småpiger, der ikke fik lart at sy af deres mødre, fik det slet ikke lært. Elsxbe Biehl oprettede en lille syskole i Hønkys og oprettede en stor hos os. Onsdag og lørdag var børnene fri for skole, da holdt vi syskole for dem. Der var 4 småpiger, der havde lang vej at gå, det var af de allerusleste tiggerbørn, dem gav jeg lov til at komme om formiddagen. Jeg satte dem så 
straks $\mathrm{i}$ arbejde, gav dem middagsmad, mens vi selv spiste, og lod dem gå hjem så tidligt, at de kunne nå hjem, før det blev mørkt. Et par af disse var meget flittige og fik lært at sy godt. Så om eftermiddagen fra 2-4 kom den store flok. De første år var der en masse børn, der kom, og der kom også et par piger fra byen for at hjælpe mig med arbejdet, især Lena Majlund var mig en tro hjælper. Senere var der ikke så mange, men jeg vedblev dog at holde skole for dem, der kom.

Når der ikke var så mange, kunne jeg få tid til at fortælle dem lidt Danmarks-historie ved siden af, for den får de jo ikke i skolen. Jeg talte også med fru Kjær i Rise, og hun fik også en stor syskole oprettet i Rise. $^{1 \mathbf{s}_{2}}$

1870 blev pastor Johansen i Haderslev og pastor Grove-Rasmussen afsatte, fordi de ikke ville bede for vore (de tyske) våbens fremgang. Grove-Rasmussen ville da gerne rejse rundt. Han holdt møder $i$ husene og talte meget godt.

Dette gav anledning til, at jeg blev kendt med Tilla Carlsen. Hun skrev mig til, at hun kunne anvise mig nogle gårde, hvor GroveRasmussen kunne komme til at tale. Han talte nu i en gård $i$ Rishjarup og én i Søes hos nogen af Tilla Carlsens familie, men han talte også $\mathrm{i}$ en gård $\mathrm{i}$ Mjøls, dog ved jeg ikke hos hvem, og derfra fik vi ham med hjem.

Det var bleven sildig, og alle var i seng, da vi kom hjem, men jeg skyndte mig at dxkke thebordet til Grove-Rasmussen og os. Da vi havde spist, og jeg havde taget af bordet, blev herrerne siddende endnu lidt og talte sammen, og jeg gik ind i den lille stue og skrev en artikel til "Dannevirke" om den salme: "Tag det sorte kors fra graven «. Jeg havde nu begyndt at skrive en del artikler, både til "Nordslesvigsk Søndagsblad « og til »Dannevirke« ...

Mr. Viney [i London] sendte mig også engang en bog med trykte predikener af ham selv. Af disse har jeg oversat en del, som jeg har făet optaget $i$ »Indre Missions Tidende«.

Senere fik jeg også opfordring fra Elfride Fibiger ${ }^{14}$ til at skrive i et tidsskrift for kvinder, dette gjorde jeg...

Den aften, Grove-Rasmussen var hos os, gik jeg ikke i seng før kl. 2 om natten og stod op igen for at få mit arbejde gjort. Om formiddagen fik jeg ham til at gå hen og besøge Truelsens svigerfader, der var meget syg og døde kort efter. 
Grove-Rasmussen holdt ofte møder hos os, og det var der flere, der gjorde. Pastor Nissen ${ }^{15}$ talte også hos os flere gange. Nielsen, der var sekretær $\mathrm{i}$ landboforeningen, fik også mange gode talere til at holde foredrag dér.

Over alt dette glemte jeg dog ikke min kxreste livsgerning, at besøge de syge, når jeg kunne få tid dertil en rolig eftermiddag, eller når jeg kunne få lavet lidt sygemad og gå derhen med det, medens de andre spiste.

Den gamle smed havde fået tuberkulose, han var dog så heldig at få sin smedie solgt ret godt, da han ikke mere havde krxfter til at arbejde $\mathrm{i}$ den. Vi lånte ham vor gamle gyngestol. I den sad han godt. Jeg besøgte ham tit, og vi skiftede mange gode ord med hverandre.

Kresten Back var også syg i længere tid, han var alvorlig troende, hans kæreste salme var den »Nu, Gud ske lov, det hjemad går «.

Den mærkeligste syge, jeg besøgte, var dog Hans maler. Han havde fået rygmarvstæring, og da denne var så fremskreden, at han ikke kunne gå, men kun sidde på en stol, blev jeg opfordret til at besøge ham. Jeg vidste, at han var fritænker, og jeg talte da først med ham om hans sygdom, men så spurgte jeg ham, om han ikke havde lyst til at læse noget for at få tiden til at gå. Jo, det ville han da gerne, han kunne godt læse, for tiden faldt ham lang.

Jeg lånte ham da forskellige bøger, bl. a. "Onkel Toms hytte«, som han læste med megen interesse. Jeg talte da hver gang med ham om de bøger, han havde læst. Da jeg nu troede, han havde modtagelighed derfor, tog jeg et bind af Blædels prædikener med og læste en af dem for ham. Han var glad ved den og bad om at måtte låne bogen. Nu syntes jeg, at han begyndte at blive vakt til troen, men jeg måtte stille ham på en prøve for at se, om det virkelig var alvor. Hans ældste søn havde giftet sig med en fattig kvinde imod faderens vilje, men hun havde et godt og venligt sind, for da maleren allerede var hjælpeløs og hans kone frugtsommelig, kom svigerdatteren til dem og gjorde alt det arbejde, som moderen ikke kunne overkomme. Maleren var dog så hård, at hun aldrig måtte komme ind i stuen, han ville ikke se hende, og hun opholdt sig så bestandig $i$ køkkenet, indtil sønnen fik tjent så meget, at han kunne betale billetten til Amerika, både for sig og sin kone. Så rejste de, og han skrev hjem til sin moder, men faderen vidste det ikke. Sønnens navn 
blev aldrig nævnt. $\mathrm{Nu}$ sagde jeg til maleren: "De har jo en søn i Amerika, nu da det ser ud til, at Deres sygdom vil ende med døden, burde De forsone Dem med ham." - »Jeg kan ikke skrive«. - $\gg \mathrm{Nej}$, men jeg kan skrive for Dem, når De vil sige mig, hvad De vil have skrevet«. - "Jeg kan ikke tale«. — "Godt, så vil jeg skrive, som jeg synes, og læse det for Dem, så kan De sige mig, om De er tilfreds«. Jeg havde taget papir og pen med, og nu gav konen mig blæk, og jeg skrev da, så godt jeg kunne, om gensidig tilgivelse og forsoning. Han begyndte at græede, såsnart jeg begyndte at læse brevet, og da jeg var færdig, spurgte jeg ham, om han var tilfreds med det, jeg havde skrevet. "Jo, det var meget godt «. Konen var også tilstede, og jeg spurgte nu, om der var mere, de ville have skrevet. Jo, det var der, noget jeg skulle tilføje, og det gjorde jeg. Så lagde jeg brevet $i$ en konvolut, skrev adressen på, lukkede brevet og tog det med for selv at give posten det.

Det var en dag mellem jul og nytår, og da jeg kom hjem, ventede der mig endnu en glæde. Nielsen havde været $i$ Ảbenrå og havde medtaget en symaskine til mig til nytårsgave.

Der kom nogen tid efter et godt og venligt brev fra malerens søn, og jeg var glad ved at se, at de var blevet forsonede...

Nielsen havde fået en mejeriassistent til at komme til Kassø for at sætte os ind $\mathrm{i}$ det nyeste på mejeriets område. Han kærnede og ostede et par dage, både hos os og hos Nis Callesen, og det var ikke blot os selv, der skulle se til og hjælpe til derved, men der var også mødt flere af byens koner for at se, hvorledes man bar sig ad dermed. Følgen var, at vi fik vandmejeri indrettet, og Nis Callesen fik en helt ny kælder bygget.

Senere fik Peters ismejeri på "Anesminde «, men siden centrifugen og dampmaskinen er blevet indført på mejerierne, skal der jo mange køers mælk til, for at det kan betale sig.

Der var engang et stort møde $i$ Bovlund $i$ to dage, jeg ved ikke så nøje, hvad år det var, jeg tænker én eller to og halvfjerds. Monrad var der og alle de ledende medlemmer $\mathrm{i}$ den danske forening. Nielsen og jeg var der begge, og jeg gjorde bekendtskab med frk. Lindberg. ${ }^{16} \mathrm{Vi}$ lå om natten i samme værelse i Laust Arnums gård. Vi sov ikke meget den nat, for vi havde så meget at tale om sammen. Hun fortalte mig, at hun havde taget en plads som lærerinde på en bondegård i Hviding, og nu arbejdede hun på at få danske 
lærerinder anbragt rundt omkring i de danske bøndergårde i Nordslesvig. Jeg fandt den plan meget god og sagde, at jeg måske kunne få nogle pladser til hendes lærerinder. Det lykkedes også virkelig at få tre lærerinder anbragte, frk. Frandsen, frk. Suhr og frk. Kejser.

Frk. Lindberg besøgte mig flere gange siden i Kassø. Engang var hun $\mathrm{i}$ længere tid hos os $\mathrm{i}$ julen og lærte de lærerinder, der var kommen der på egnen, forskellige husflidsarbejder.

Kort efter, at jeg havde gjort hendes bekendtskab, skiftede hun plads og kom til en gårdejer Thyssen $\mathrm{i}$ Randerup. Efter nogle års forløb blev hun alligevel ked af at leve sammen med bønderne. Hun købte da en nedlagt herredsfogedbolig i Visby og oprettede en skole til uddannelse af danske lærerinder. Men da hun var med på sønderjydernes vestjyske tur, blev hun udvist. Hun måtte nu sælge sin skole med tab og flyttede sin lærerindeskole til Vamdrup. Her ville det imidlertid ikke rigtig gå, hun fik for få elever og måtte opgive skolen. Hun havde nu fået bevilget en lille pension årlig af den danske regering for hendes fars fortjenesters skyld og har siden boet i Kolding.

Imidlertid var Grove-Rasmussen blevet præst i Harte, og det var blevet danske præster forbudt at tale i Sonderjylland. Det var derfor heldigt, at vi med lærerindernes hjælp kunne få oprettet en husflidsforening, der gav anledning til små hyggelige møder, hvor der blev sunget danske sange, og som var ret fornøjelige.

Hvert forår blev der så holdt et større møde med udstilling af sagerne.

Et efterår var frk. Frandsen og jeg til et stort vennemøde i 2 dage. Den første dags eftermiddag samledes vi til møde $i$ en stor have ved Dons mølle. Der blev holdt mange taler, mindst 6 eller 7. Midt imellem var der en pause, hvor der blev spist af medbragte madkurve. Om natten blev de, der ikke havde logi, indkvarteret $i$ byen. Frk. Frandsen og jeg kom til at bo hos en skrædder. Vi lå sammen $i$ een seng. Det var jævne folk, men meget flinke og venlige.

Den følgende dag skulle der være gudstjeneste i Almind kirke. Så gjaldt det om at komme til at køre, for der var langt til Almind. Vi kom til at køre med Jørgen Ravn, en fætter til Per Ravn i Jelling. Han var gårdejer i Dons, hans kone hed Maren, det var nogle dejlige troende mennesker. De havde tre vogne i kirke den dag, og vi fik talt meget sammen undervejs, mens vi kørte til Almind. 
I kirken holdt pastor Wagner, højskoleforstander Schrøders svoger, skriftetalen, og flere forskellige prxster hjalp hverandre med at uddele nadveren, men kirken var så overfyldt, at luften blev beklemt. Der var et par, der besvimede. Så gik nogle degne omkring og slog ruder ud. $\mathrm{Da}$ aftengudstjenesten var forbi, skulle pastor Andreas Leth prædike. Og nu blev der foreslået, at vi skulle gå ud på kirkegården. Det gjorde vi så. Dér var jo plads nok. Så prædikede pastor Leth på kirkegården.

Et andet år gjorde jeg en rejse til København for at besøge min mands broder og hans familie. Jeg logerede hos dem og var der vist henimod en otte dages tid. $\mathrm{Da}$ jeg var søndag over, var vi i Vartov og hørte pastor Brandt prædike.

Tante blev så glad derved, at hun var ved at græde af glæde, for hun var troende.

Da gudstjenesten var endt, gik hun hjem for at lave middagsmad, men vi andre gik til Thorvaldsens Museum ...

Missionær Skrefsrud ${ }^{17}$ var kommet til Danmark og holdt møder rundt omkring. I længere tid boede han på Tirsbæk ved Vejle fjord. Så skrev Nielsen til ham, om han ville komme til os, dersom vi kunne skaffe ham tilladelse til at prædike $i$ en kirke eller to. Han svarede, at det ville han gerne.

Så var jeg i Ảbenrå en dag. Først gik jeg op til provsten ${ }^{18}$ og spurgte ham, om han ville give tilladelse til, at Skrefsrud predikede i Åbenrå kirke. "Ja«, sagde provsten, "det har jeg ikke noget imod, jeg holder ikke af, at grundtvigianerne kommer med deres nye anskuelser, men en missionær som Skrefsrud må nok komme med noget godt, men jeg råder ikke for det alene, det kommer også an på, om pastor Tonnesen vil give sit minde dertil «.

$\mathrm{Nu}$ gik jeg lige til pastor Tonnesen, ${ }^{19}$ bankede på døren til hans kontor og gik lige ind. Jeg fortalte ham nu, hvem jeg var, og at jeg kom lige fra provsten, og meddelte ham, hvad denne havde sagt. $\gg \mathrm{Og}$ når nu provsten har givet sin tilladelse, så kan De naturligvis ikke have noget derimod «. Tonnesen var fuldstændig overrumplet, han kunne jo ikke undgå at sige ja, når han ville gxlde for en kristen præst, og det gjorde han da også. Så gik jeg til provsten igen og meddelte ham dette. $\mathrm{Og}$ vi fik da lov til at skrive til Skrefsrud. Vi havde også talt med pastor Kjær i Rise, og han ville gerne have ham til at tale i Rise kirke. $\mathrm{Vi}$ vidste jo, at kirkerne nok skulle blive 
propfulde. Men da nu Nielsen skrev dette til ham, fik vi det svar, at han havde fået halssyge, og at lægen havde forbudt ham at tale, så der blev alligevel ikke noget af disse møder.

$\mathrm{Ja}$, nu er det kun salmebogssagen, jeg har tilbage at fortælle om. Pastor Topsøe $e^{20}$ har fortalt den udførlig, og deraf har jeg taget en afskrift, som ligger i min skuffe. Alligevel har jeg lyst til at skrive lidt om den, således som jeg opfatter den.

$\mathrm{Vi}$ havde fået synodalindretning $\mathrm{i}$ vor provins. Dens betydning og værd har de danske præster ikke godt ved at forstå. Hverken min svoger Balslev eller pastor Topsøe syntes godt om den, men den har det fortrin, at menigheden kan komme til orde. Og også lægmænd har ret til at tale med om kirkelige sager. Jeg tror, det ville være godt, om vi havde noget lignende her i Danmark. I hver menighed er der representanter, disse skal varetage det arbejde, der tidligere blev gjort af kirkeværgerne. Men ved siden af er pålagt som pligt det, vi kalder menighedspleje på alle de områder, hvor de har evne og lejlighed dertil. I folkerige menigheder er der flere repræsentanter end i de små. Der er også kirkexldste, og disse er de styrende i menighedsplejens kreds. Nielsen blev straks valgt til kirkexldste.

Så er der provstisynoden. Alle præster i provstiet er medlemmer af den. Men så vælger menighederne dertil dobbelt så mange lægmænd, som der er præster, idet man går ud fra, at præsterne nok alligevel skal hævde deres meninger, fordi de har fyldigere udvikling og bedre talegaver. Nielsen blev også valgt ind i provstisynoden.

Så er der noget, der hedder synodaludvalg. Det skal overtage de forretninger, som før påhvilede visitatorerne, således at to lægmænd, der er valgt til synodaludvalget, træder $i$ stedet for amtmanden og skal sammen med præsten holde visitats i alle kirker. De skal også, når et embede bliver ledigt, foreslå tre kandidater til besættelse eller til valg. Dog skal deres forslag stadfæstes af konsistoriet. Og det skete flere gange, at konsistoriet strøg en kandidat, som synodaludvalget havde foreslået, når han var for dansk, og satte en anden i stedet, der var regeringen mere behagelig.

Nielsen blev også medlem af synodaludvalget.

Så er der provinssynoden. Til denne blev første gang valgt pastor Michaelsen, Bjolderup. Men han forholdt sig helt rolig. Og der blev 
ikke udrettet noget $\mathrm{i}$ hans tid. Jeg tror nok, valget gjaldt for tre ăr.

Næste gang blev pastor Kier i Øster Løgum valgt $\mathrm{i}$ hans sted. Og Nielsen blev valgt som lægmand for Åbenrå amt. Hvem den anden lægmand for Ảbenrå amt var, ved jeg ikke, for der var flere andre lægmænd, der øvede større indflydelse, især Amorsen fra Haderslev, og Nissen, Viby, fra Als.

$\mathrm{Da}$ Nielsen rejste, gav han mig hånden på, at han skulle nok få noget udrettet. Og det lykkedes da også $\mathrm{i}$ denne samling at føre salmebogssagen igennem.

1881 indbragte Nielsen $\mathrm{i}$ prostisynoden et forslag om at få indført en ny dansk salmebog i de nordslesvigske kirker. Deri blev han støttet af nogle lægmænd (Asmussen, Søes), men modarbejdet af de fleste præster. De mest tysksindede præster ville have den af $\mathrm{Va}$ lentiner ${ }^{21}$ omarbejdede Pontoppidan indført. Men den ville befolkningen absolut ikke have, for den var beregnet på fortyskning. $\mathrm{Og}$ man tænkte at kunne holde folk hen med den, indtil man kunne påtvinge den tyske gudstjeneste og få en tysk salmebog indført.

De mere mådeholdne præster, deriblandt Tonnesen, arbejdede på at få Meyer-Boesens omarbejdelse af Pontoppidan indført, tillige med et lille tillæg af de nyere bedste danske salmer. Alle råbte de på, at vi ville berøve den sønderjyske menighed de gode gamle danske salmer, som de kendte og elskede. Og man gjorde, hvad man kunne, for at indbilde befolkningen dette.

Dette måtte vi modbevise, således at befolkningen kunne forstå det. Pastor Topsøe havde givet Nielsen et udkast til en salmebog, som han og pastor Nansen i Taps havde udarbejdet. Dette udkast var bygget over Fengers salmebog. Og vi var klar over, at det ikke ville kunne opnå at få privilegium i Sønderjylland, fordi det sluttede sig til en i Danmark trykt og brugt salmebog.

Så sagde jeg til Nielsen en aften: "Skal vi ikke selv lave et udkast til en salmebog, bygget over Meyer-Boesens salmebog? «— "Tror du, vi kan det? « - "Det kan vi sagtens, vi har jo Topsøes udkast, som vi kan støtte os til."

Så gav vi os til arbejdet. Fra først af havde vi tænkt os kun at udtage de ensformige og kedelige salmer af Meyer-Boesen og i stedet for disse at indsæette de bedste nye salmer, så at vi beholdt numrene uforandrede, da vi så mente at kunne få den trykt som en ny udgave af Meyer-Boesen, der jo havde privilegium. 
Dette viste sig snart ugørligt, da der ikke var ret mange festsalmer i Meyer-Boesen. Og blandt de nye salmer var der en mængde festsalmer, som absolut måtte med, men vi arbejdede alligevel frejdigt videre.

Det var nogle dejlige aftener, da vi arbejdede sammen med denne gerning. Når vi havde drukket the om aftenen, fyldte vi thepotten med vand og satte den i kakkelovnen. Når så folkene var gået i seng, begyndte vi vort arbejde. Vi var begge lige interesserede og begejstrede derfor, også enige i, hvad der skulle medtages, og hvad der skulle udstødes.

Begyndte vi så at blive trætte, tog vi en kop the med en tvebak til, og så arbejdede vi videre. Det var herlige aftener, noget af det bedste, jeg har oplevet.

$\mathrm{Da}$ udkastet var færdigt, fik Nielsen "Nordslesvigsk Søndagsblad « til at trykke det og sende det med bladet til alle sine abonnenter.

$\mathrm{Nu}$ kom der fart i den sag. Nielsen kom til at korrespondere med masser af mennesker, der interesserede sig for den sag og skrev til ham derom.

De tyske præster udtalte også deres mening $\mathrm{i}$ blade og søgte at nedrakke især Grundtvigs salmer. Men de kunne ingen vegne komme med deres falske påstande og helt misforståede udlæggelse af Grundtvigs salmer. De blev straks modbeviste.

I provinssynoden [1883] fik Nielsen pastor Kier til at indbringe forslaget om en ny salmebog for Nordslesvig. Og alle danske medlemmer af synoden sluttede sig sammen om dette. De var jo imidlertid for få til at føre sagen igennem. Men Nielsen forstod at vinde flere. Han var ingen taler, men havde udmærkede evner til i privat samtale enkeltvis at vinde folk for sagen.

Således vandt han generalsuperintendent Godt, konsistoriets formand, commissarius dr. Mommsen, pastor Dohrn i Altona, Carl Fischer, som jo også kendte mig, og adskillige andre. Jeg havde oversat en del af Grundtvigs salmer til tysk. Dem fik Nielsen med, og viste dem til nogle af de tyske medlemmer af synoden, så at de kunne se, at det var med urette, at Grundtvig var blevet forkxtret.

Dertil kom, at der netop i den tid blev vedtaget udgivelsen af en ny tysk salmebog. Og de tyske medlemmer, der blev støttet af de danske deri, lovede til gengxld at støtte de danske $\mathrm{i}$ deres ønsker, 
ligesom også den ydre form, tryk, format o.s.v. blev vedtaget i lighed med den tyske salmebog.

Der blev vedtaget, at de 5 danske provstisynoder skulle vælge hver 2 mand. Og af disse 10 ville konsistoriet udtage 5, som skulle lave salmebogen.

Det var jo et godt resultat, og dermed kom Nielsen hjem. Dog skrev de endnu $i$ bladene, som om sagen ikke var ført igennem. Men så oversatte vi det tyske referat af forhandlingerne på dansk og sendte det til "Dannevirke«, så kunne enhver da se, at vi havde sejret. Og den følgende dag kom der også en artikel af Amorsen, hvori han slog dette fast.

Nielsen flyttede jo til Danmark ${ }^{22}$ [1884], før salmebogen blev udarbejdet, men han havde dog endnu så megen indflydelse på de mænd, der var medlemmer af provstisynoderne, at $i$ alle 5 provstisynoder de mænd blev valgte til udarbejdelsen af salmebogen, som Nielsen havde foreslået dertil. -

\section{NOTER}

1. Fldste søn $\mathrm{i}$ xgteskabet, født $\mathrm{i}$ december 1861.

2. Datter af senere biskop i Ribe C. F. Balslev, gift med senere stiftsprovst $i$ Ribe Chr. F. Koch. Balslev blev som stiftsprovst i Ribe 1853 gift med Marie Elise Hansen, Amalies ældre søster. 1860-67 var han sogneprest i Nr. Broby på Fyn.

3. Det drejer sig om det indremissionsk pregede danske kirkearbejde, som samledes om bladet $*$ Elias , redigeret af pastor Grove-Rasmussen 1867-74. Den 20. august 1868 stiftede man $\mathrm{i}$ Vojens en lægmandsvenlig $\gg$ Kirkelig forening til Guds riges fremme i Slesvig*, der dog med krigen i 1870 og de ledende præsters afskedigelse og flytten til kongeriget måtte indstille sit virke. Men præsterne Grove-Rasmussen og J. Johansen, tidligere Haderslev, kom fortsat over grænsen til månedlige møder $\mathrm{i}$ private hjem, indtil også denne gæsteoptræden nord fra blev forbudt i 1874 af de projsiske myndigheder. Lauenborgeren Harald Bruun v. Neergaard i Alten, født 1837 i Ratzeburg, stærkt tysksindet, døde $\mathrm{i}$ sit forste præsteår her 1867, fra 1864 i Kliplev. A. Michaelsen, født 1830 i Kastvrå, Sommersted sogn, præst i Bjolderup 1866-80. E. Claussen, fodt 1832 i Tonder, præst i Dybbøl 1865-1902. H. Lawaetz, født 1832 i Holsten, præst i Skrydstrup 1865-71. A. Grove-Rasmussen, født 1836 i Horsens, kapellan i Gram 1864, prast i Fole 1868-70, afskediget, fri prest i Gram 1870-74. J. Johansen, fredt 1827 i Nakskov, hospitalsprest i Haderslev 1860-70.

4. Pastor Peter Kier, præst i Øster Løgum 1802-1834.

5. Chr. Grønning, født 1813 i Fredericia, missionær i Indien 1845-65, dansk præest i Ảbenrå 1868-73.

6. Rebslager og gårdejer i Jegerup Mads Jensen, født 1839 i Asperup, Fyn, kolporter og lægprædikant i Foreningen af 1868, sluttede sig 1874 til frimenigheden, død 1910 i Haderslev. 
7. Se note 3 .

8. G. G. Jakobsen, født 1844 i Haderslev, prast i Randerup 1874-87, flyttet til kongeriget.

9. Chr. Bruhn, født 1828 i Augustenborg, dansk præst i Haderslev 1863, i Gram 1877-87, flyttet til kongeriget.

10. A. Leth, født 1822 i Nyborg, dansk præst i A benrå 1850-63, i Middelfart 1870-94.

11. Jes Nielsens morbror, efter hvem han havde overtaget gården i Kassø, boede på gården til sin død $\mathrm{i}$ januar 1870.

12. Fru Nielsens plejedatter, født i Flensborg.

13. D. Clausen, født 1843 i Angel, privatskolelærer i Bolderslev 1867-1879, degn i Bjolderup 1888-1904.

13a. Pastor M. Kjær, født 1806 i København, prast i Rise 1857-82.

14. Hendes socialt prægede forfatterskab har uden tvivl inspireret Amalie Nielsen.

15. H. Fr. Nissen, født i Snestrup, Fyn, præst i Asserballe 1871, i Gram 1888-99.

16. Elise Lindberg, datter af Grundtvigs nære medarbejder, magister Jac. Chr. Lindberg, dansk privatlarerinde fra 1872 i Råhede, Hviding, Randerup og Ottersbøl mølle, Mjolden sogn, oprettede 1880 et privatseminar for unge kvinder $\mathrm{i}$ Visby, lukket i 1884 efter hendes udvisning, fortsat i Vamdrup til 1888. I alt har 48 privatlærerinder fået uddannelse hos hende, også med husflid som fag.

17. L. O. Skrefsrud, nordmand, missionær i Santalistan sammen med H. P. Børresen.

18. F. G. Göttig, født 1813 i Flensborg, provst i Ābenrå 1864-92.

19. H. Tonnesen, født i Bastrup ved Vamdrup 1854, præst i Ảbenrå 1880, i Hoptrup 1888-1927, leder af Indre Mission i Nordslesvig 1886-1920.

20. Pastor Topsøe i Hejls var kontaktmand for fremskaffelsen af nyere dansk salmestof, især Grundtvigs, til salmebogskommissionen i Nordslesvig.

21. Pastor C. A. Valentiner, født 1815 i Flensborg, prast i Gl. Haderslev og forstander for det nordslesvigske præsteseminar 1870-91, forsøgte at nyudgive Pontoppidans salmebog fra 1740.

22. Ægteparret boede forst på Vejleegnen, derefter et par andre steder. Dets grav findes på Harte kirkegård. Jes Nielsen dade den 2. april 1901, Amalie Nielsen den 21. april 1913. 